\title{
Strategic priorities for development of housing construction and renovation sector
}

\author{
Elena Voskresenskaya ${ }^{1, *}$, Lybov Vorona-Slivinskaya ${ }^{2}$, and Lybov Achba $^{3}$ \\ ${ }^{1}$ Peter the Great St.Petersburg Polytechnic University, Polytechnicheskaya str., 29, 195251, St. \\ Petersburg, Russia \\ ${ }^{2}$ Saint Petersburg State University of Architecture and Civil Engineering, 2nd Krasnoarmeyskaya str., \\ 4, 190005, St. Petersburg, Russia \\ ${ }^{3}$ Financial University under the Government of the Russian Federation, St. Petersburg branch, \\ Sezzhinskaya str., 15-17, 197198, St. Petersburg, Russia
}

\begin{abstract}
The article highlights the problem of sustainable development of the living environment and living standards of the population, which is rather relevant for the governments of most developed countries including Russia. In recent years, the anthropogenic impact of aggressive external medium on the quality of human life increases, which reduces the working capacity of citizens and consequently lowers their labor productivity. The implementation of «Concept for the Transition of the Russian Federation to Sustainable Development», which was elaborated and adopted in 1996, implies a gradual transition to the balanced solution of pressing social and economic issues and problems that concern preserving natural resources in order to meet the needs of present and future generations. The authors emphasized the need for a scientific-theoretical and methodological substantiation of preparing the strategic priorities of the housing development planning with a focus on creating competitive residential housing and renovation projects. The authors note that the greening of housing construction and renovation industry helps to ensure high living standards and contributes not only to improving human well-being and increasing person's lifetime but also enhances his or her working capacity and labor productivity. The elaboration of strategic priorities of the housing industry development involves the consideration of current challenges of the national economy.
\end{abstract}

\section{Introduction}

For the sustainable development of living environment and living standards of the population, the federal and regional authorities of the Russian Federation took certain measures to solve the housing problem, which is the most pressing socio-economic problem. Due to implementation of those measures, the volume of commissioned housing increased from 30.3 million $\mathrm{m}^{2}$ to 85.3 million $\mathrm{m}^{2}$ and the average housing per capita grew from $19.2 \mathrm{~m}^{2}$ to $24.4 \mathrm{~m}^{2}$ within the period from 2000 to 2017 .

\footnotetext{
${ }^{*}$ Corresponding author: elenvoskr@mail.ru
} 
However, the severity of the housing problem in Russia has increased significantly, despite all the measures that had been taken by the authorities for the 25 -year reform period and are being taken right now. The situation surely was aggravated by the following factors: restrictions on budget financing of the housing industry; fall in the effective demand of the population for housing and renovation facilities, reduction of housing affordability; disposal of dilapidated housing; fulfillment of state social obligations to certain categories of citizens (veterans, orphans, military officers, medical workers, teachers); the inconsistency of the National Program «Affordable and Comfortable Housing for the Citizens of Russia».

Nevertheless, the main reason of exacerbation of the housing problem is the lack of targeted state policy in the housing industry. In particular, for the 25 years of reforms, the government has not developed or adopted a strategy for the development of this industry. The participants of the residential real estate market are not able to develop or implement not only their long-term goals and programs, but also to reorient their activities with regard to the priorities and objectives of the country, because there is no state-specified development direction for this segment of the national economy.

When forming strategic priorities for the development of the housing industry based on the creation of competitive housing construction and renovation under the conditions of increased consumer demands and the need to comply with international and national standards for its development, the results of studies conducted by a number of domestic and foreign scientists in relevant fields and areas of economic science were studied: E. A. Maltseva, M. V. Matveeva, S.I. Sai, D. V. Khustov, M.V. Hotuleva [1- 5]. The authors investigated the problems of the housing industry economy, as well as the characteristics and properties of competitiveness of housing construction and renovation, and also empirically revealed and substantiated modern housing consumer preferences of citizens: the quality and environmental friendliness of housing construction and renovation, which was noted by authors many times [6-14].

\section{Materials and Methods}

Within different periods of the Russian history, the housing industry changed its goals, aims, priorities, principles and development baselines. At the same time, scientists not only proposed different views, strategic priorities and scientific approaches, but also opposed them to each other at different stages of the evolutionary development of the theory and practice of the functioning and development of the studied industry. The emergence of international ISO standards, one of the main principles of which is "consumer orientation", necessitated taking this factor into account when planning the strategic development of national economy sectors.

The aim of the study is to define strategic directions for the housing industry development, taking into account the increased needs of the population and the quality and ecological performance requirements of international and national standards to housing and renovation facilities.

During the research, the authors used general scientific methods of systemic and comparative analyzes, expert assessments, multifactor dependencies modeling and modeling of complex system financing, sociological research methods; methods of statistical analysis, etc.

The study was informationally based on legislative and regulatory legal acts of the Russian Federation on issues of competition, quality and assessment of compliance of housing construction and renovation projects with ecological performance; analytical and statistical data. 


\section{Results}

The authors educed new consumer preferences in residential housing. High quality and environmental friendliness of housing construction and renovation projects became primary for a significant number of Russian citizens (89.1\%) regardless of their gender, age, income, education, occupation or social class.

The trends in the development of housing industry that are relevant and fair for the recent past and even for the present, cannot be considered as the only true trends both in the long and in the medium terms, since consumer preferences and priorities in the housing market always change and are determined by sometimes unpredictable behavior of its subjects. The exacerbation of the housing problem in Russia was largely influenced by the income level stratification of the population and by the presence of the new need for both quantity and quality of housing construction and renovation projects among high and middle-class citizens. At the same time, although there are a lot of theoretical studies of various aspects of the housing industry, there is currently no justification for the strategic priorities of its development in the Russian Federation that is adequate not only to the requirements of a modern market economy in terms of profitability for construction companies, but also to the increased public demand for quality and environmental friendliness of housing and renovation projects and of external environment.

\section{Discussion}

The strategic priorities of the housing industry in terms of the competitiveness of housing construction and renovation are based on the integrated approach: in one respect, it is meeting the growing needs of solvent customers for quality and environmental friendliness of the created projects taking into account the price of consumption, in another respect - the efficiency of activities of housing construction companies.

In accordance with the Estimates of the long-term socio-economic development of the Russian Federation to 2030 and the Strategy for the innovative development of the construction industry to 2030 and due to the increase in the socio-ecological and economic efficiency of the strategic priorities for the development of the housing industry, the economic efficiency characteristics are expected to grow. For instance, compared to 2010 GDP will decrease by $23 \%$ in 2020 , by $41 \%$ in 2030 , and labor productivity will increase 1.5 times in 2020 compared to 2010 and respectively 2.3 times in 2030 . The downward trend in construction output, which started in 2014, was observed in 2015-2016 and continued in 2017.

In accordance with the federal targeted investment program for 2017 approved by the Ministry of Economic Development of Russia (with adjustments of January 1, 2018), 624.6 billion rubles were allocated. The part allocated from the federal budget was 603.6 billion rubles intended for implementing 1346 capital construction projects, acquiring real estate objects and taking certain measures (integrated investment projects). For 255 objects of the total number, it was planned to carry out only design and survey works. 228 projects of 404 that were planned to be finished in 2017 were commissioned, of which 208 were put in commission to the full extent and 20 - partially.

As of January 1, 2018, the technical readiness of 375 sites ranged from $51.0 \%$ to $99.9 \%$ (excepting projects at the stage of design or survey works).

Table 1 provides information on the commissioning of residential buildings in Russia [15]. 
Table 1. Commissioning of residential buildings in the Russian Federation, $\mathrm{mln} \mathrm{m}^{2}$ of total living area.

\begin{tabular}{|c|c|c|c|c|c|}
\hline Year & Totally built & \multicolumn{2}{|c|}{ Including } & \multicolumn{2}{c|}{$\begin{array}{c}\text { Relative share in general } \\
\text { terms, \% }\end{array}$} \\
\cline { 3 - 6 } & & $\begin{array}{c}\text { By the } \\
\text { population at } \\
\text { the expense of } \\
\text { their own and } \\
\text { attracted funds }\end{array}$ & $\begin{array}{c}\text { By housing } \\
\text { construction } \\
\text { cooperatives }\end{array}$ & $\begin{array}{c}\text { Residential } \\
\text { buildings of } \\
\text { the } \\
\text { population }\end{array}$ & $\begin{array}{c}\text { Residential } \\
\text { buildings of } \\
\text { housing } \\
\text { construction } \\
\text { cooperatives }\end{array}$ \\
\hline 2010 & 58.4 & 25.6 & 0.3 & 43.7 & 0.6 \\
\hline 2011 & 62.3 & 26.8 & 0.4 & 43.0 & 0.6 \\
\hline 2012 & 65.7 & 28.4 & 0.3 & 43.2 & 0.4 \\
\hline 2013 & 70.5 & 30.7 & 0.5 & 43.5 & 0.7 \\
\hline 1014 & 84.2 & 36.2 & 0.4 & 43.0 & 0.4 \\
\hline 2015 & 85.3 & 35.2 & 0.6 & 41.2 & 0.7 \\
\hline 2016 & 80.2 & 31.8 & 1.0 & 39.6 & 1.2 \\
\hline 2017 & 79.2 & 33.0 & 0.8 & 41.6 & 1.0 \\
\hline
\end{tabular}

Table 2 provides information on the housing stock of the Russian Federation [16].

Table 2. Housing stock of the Russian Federation, $\mathrm{mln} \mathrm{m}^{2}$ of total living area.

\begin{tabular}{|c|c|c|c|c|c|}
\hline & 2000 & 2010 & 2014 & 2015 & 2016 \\
\hline $\begin{array}{l}\text { Housing stock, total } \\
\text { including: }\end{array}$ & 2787 & 3231 & 3473 & 3581 & 3653 \\
\hline private & 1819 & 3765 & 2999 & 3232 & 3306 \\
\hline $\begin{array}{l}\text { of which owned by } \\
\text { citizens }\end{array}$ & 1620 & 2657 & 2873 & 3118 & 3188 \\
\hline state & 177 & 139 & 116 & 116 & 127 \\
\hline municipal & 739 & 321 & 233 & 205 & 192 \\
\hline other & 52 & 6 & 12 & 13 & 13 \\
\hline $\begin{array}{l}\text { Urban housing stock, } \\
\text { total } \\
\text { including: }\end{array}$ & 2020 & 2333 & 2522 & 2612 & 2669 \\
\hline private & 1163 & 1951 & 2117 & 2328 & 2384 \\
\hline $\begin{array}{l}\text { of which owned by } \\
\text { citizens }\end{array}$ & 1022 & 1872 & 2015 & 2234 & 2285 \\
\hline state & 143 & 121 & 105 & 105 & 116 \\
\hline municipal & 673 & 256 & 178 & 154 & 143 \\
\hline other & 41 & 5 & 9 & 10 & 11 \\
\hline $\begin{array}{l}\text { Rural housing stock, } \\
\text { total } \\
\text { including: }\end{array}$ & 767 & 898 & 951 & 969 & 984 \\
\hline private & 656 & 814 & 882 & 904 & 922 \\
\hline $\begin{array}{l}\text { of which owned by } \\
\text { citizens }\end{array}$ & 598 & 785 & 858 & 884 & 903 \\
\hline state & 34 & 17 & 11 & 11 & 11 \\
\hline municipal & 66 & 66 & 56 & 52 & 49 \\
\hline other & 11 & 1 & 3 & 3 & 3 \\
\hline
\end{tabular}

Table 3 provides information on the construction of residential buildings in JanuaryAugust 2018 by constituent entities of the Russian Federation [15]. 
Table 3. Construction of residential buildings by constituent entities of the Russian Federation during January-August 2018, thousand square meters of total living area.

\begin{tabular}{|c|c|c|c|c|}
\hline \multirow[t]{2}{*}{ Territory } & \multicolumn{2}{|c|}{ Areas commissioned } & \multicolumn{2}{|c|}{$\begin{array}{l}\text { Of the total amount commissioned } \\
\text { by the population }\end{array}$} \\
\hline & $\begin{array}{l}\text { Since the } \\
\text { beginning } \\
\text { of the year }\end{array}$ & $\begin{array}{l}\text { As percentage to the } \\
\text { corresponding period } \\
\text { of the previous year }\end{array}$ & $\begin{array}{l}\text { Since the } \\
\text { beginning } \\
\text { of the year }\end{array}$ & $\begin{array}{l}\text { As percentage to the } \\
\text { corresponding period } \\
\text { of the previous year }\end{array}$ \\
\hline $\begin{array}{l}\text { Totally in } \\
\text { Russia }\end{array}$ & 39217.5 & 98.9 & 20040.0 & 122.1 \\
\hline $\begin{array}{l}\text { Central } \\
\text { Federal } \\
\text { district }\end{array}$ & 12247.5 & 106.6 & 6221.2 & 126.8 \\
\hline $\begin{array}{l}\text { Northwestern } \\
\text { Federal } \\
\text { district }\end{array}$ & 4896.5 & 93.4 & 1619.2 & 180.5 \\
\hline $\begin{array}{l}\text { Southern } \\
\text { Federal } \\
\text { district }\end{array}$ & 4943.2 & 97.2 & 2495.6 & 103.5 \\
\hline $\begin{array}{l}\text { North } \\
\text { Caucasus } \\
\text { Federal } \\
\text { district } \\
\end{array}$ & 1753.4 & 101.3 & 1135.9 & 110.9 \\
\hline $\begin{array}{l}\text { Volga } \\
\text { Federal } \\
\text { district } \\
\end{array}$ & 8120.4 & 97.8 & 4720.3 & 113.7 \\
\hline $\begin{array}{l}\text { Ural federal } \\
\text { district }\end{array}$ & 2792.3 & 94.9 & 1554.5 & 135.1 \\
\hline $\begin{array}{l}\text { Siberian } \\
\text { Federal } \\
\text { district }\end{array}$ & 3408.1 & 93.0 & 1824.7 & 134.0 \\
\hline $\begin{array}{l}\text { Far Eastern } \\
\text { Federal } \\
\text { district }\end{array}$ & 963.2 & 95.3 & 423.2 & 116.5 \\
\hline
\end{tabular}

Therefore, the elaboration of priorities, incentives and conditions for the construction of housing and renovation objects will allow attracting more enterprises' funds and financial savings of solvent citizens into the economic cycle of Russia. The increasing extent of housing construction determines the multiplier effect in the national economy exerted by the construction and related industries on the basis of the expanded renewal of the housing construction and renovation projects taking into account the fulfillment of the quality and environmental requirements. Thus, the objective function of the strategy for the development of the housing industry is aimed at achieving a synergistic socio-ecological and economic effect of the functioning of all sectors of the national economy.

The following principles should become the main in the formation of strategic priorities for the development of the housing industry:

1. The principle of joint social responsibility of the state and an individual in ensuring the quality of life by improving the living conditions of citizens.

2. The principle of the qualitative development of the innovative potential of the housing industry.

3. The principle of quantitative assessment of the quality of housing and renovation projects.

4. The principle of sustainable development of the housing industry.

5. The principle of adequacy and affordability of housing as an indicator of sustainable socio-economic development. 


\section{Conclusions}

New strategic prospects for the development of the housing industry should be focused on the dynamically changing needs and increasing demand of the population for high-quality and environmentally friendly housing construction and renovation projects. Such projects being implemented not only ensure the growth of profitability and competitiveness of construction and development companies, but also reduce the consumption cost of such objects due to the decrease of operating costs. Implementation of such projects also contributes to the manifestation of the social effect in terms of maintaining public health and increasing the working capacity and labor productivity of working citizens.

Theoretical theses and practical approbation have revealed the prospects for further research, which consist in improving the ways of increasing quality and environmental friendliness of the living environment. These measures will improve the socio-ecological and economic efficiency of the studied segment of the national economy and ensure decent standard of living for the population.

\section{References}

1. E.A. Maltseva, Gosudarstvennaya ekologicheskaya ekspertiza: problemy i protivorechiya deystvuyushchikh norm prirodookhrannogo zakonodatel'stva 2, 19-32 (2014)

2. M.V. Matveeva, Ekologicheskaya ekspertiza kak etap razvitiya lend-developmenta 4, 33-36 (2013)

3. S.I. Sai, Gosudarstvennaya ekologicheskaya ekspertiza v Rossii: stanovlenie, razrushenie, vozrozhdenie 6, 16-20 (2014)

4. D.V. Khustov, Problemy pravovogo regulirovaniya ekologicheskoy ekspertizy na sovremennom etape 5, 29-44 (2012)

5. M.V. Hotuleva $1325-42$ pp (2012)

6. E. Voskresenskaya, V. Snetkov A. Tebryaev, Z. Askarov, V 2017 MATEC Web of Conferences 106, 08055 (2017)

7. E. Voskresenskaya, V. Snetkov, A. Tebryaev, V E3S Web of Conferences 33, 03051 (2018) doi.org/10.1051/e3sconf/20183303051

8. E. Voskresenskaya, L. Vorona-Slivinskaya, V E3S Web of Conferences 33, 03052 (2018) https://doi.org/10.1051/e3sconf/20183303052

9. E. Voskresenskaya, D. Mokhorov, A. Tebryaev, Matec Web Of Conferences 170, 01058 (2018) DOI https://doi.org/10.1051/matecconf/201817001058

10. E. Voskresenskaya, N. Zhilskiy, E. Shariapova Matec Web Of Conferences 170, 01057 (2018) DOI https://doi.org/10.1051/matecconf/201817001057

11. P.K. Sun, L. Vorona-Slivinskaya, E. Voskresenskaya, IOP Conference Series: Earth and Environmental Science 90 (2017) https://doi.org/10.1088/1755-1315/90/1/012073

12. E. Voskresenskaya, L. Vorona-Slivinskaya, S. Panov, MATEC Web of Conferences 193, 02025 (2018) doi.org/10.1051/matecconf/201819302025

13. E. Voskresenskaya, L. Vorona-Slivinskaya, A. Loiko, Constitutional-legal issues of ensuring environmental safety in modern Russia 8(19), 57-59 (2018)

14. E. Voskresenskaya, L. Vorona-Slivinskaya, A. Loiko, Economic and legal problems devastated territories in the Russian Federation 7(18), 62-65 (2018)

15. Regiony Rossii/ Sotsial'no-ekonomicheskie pokazatel R32 (2017) 
16. Russian Statistical Yearbook, 686 (2017) 